\title{
Soil moisture in forest island and adjacent ecosystems in Sub-Saharan Region
}

\author{
Amelie B. BOUGMA ${ }^{1,2^{*}}$, Korodjouma OUATTARA ${ }^{1}$, Halidou COMPAORE ${ }^{2}$ and \\ Hassan B. NACRO ${ }^{3}$ \\ ${ }^{I}$ Institut de l'Environnement et de Recherches Agricoles (INERA), Burkina Faso, 04 BP 8645 Ouagadougou \\ 04, Burkina Faso \\ ${ }^{2}$ Centre National de Recherches Scientifiques et Technologique (CNRST) BP 7047 Ouagadougou, Burkina \\ Faso Fax: +22650315003 \\ ${ }^{3}$ Université Nazi BONI (UNB), 01 BP 910, Bobo-Dioulasso, 01 Burkina Faso. \\ ${ }^{*}$ Corresponding author; E-mail: ameliebougma@yahoo.fr ; Tel: 0022670963094
}

\section{ACKNOWLEDGMENTS}

The authors are grateful to the Royal Society-DFID for funding the study through the Soil of Forest Island in Africa (SOFIIA) ACBI project.

\author{
Received: 14-08-2020 $\quad$ Accepted: 24-12-2020 $\quad$ Published: 31-12-2020
}

\begin{abstract}
Forest islands are widely distributed throughout West Africa savanna landscape. Stated as direct outcome of anthropogenic activity, these mosaics are often found around villages and are known for their unique and luxuriant characteristics of tropical rainforest. Althought significant studies focus on their ecology, works on edaphic factors that govern their establishment are very scare. The objective of the current study was to evaluate soil moisture dynamics in forest islands compared to that of surrounding savannas and farmlands at five sites located along a precipation gradient in Burkina Faso. For two years, from 2016 to 2017, soil moisture was monitored at a depth of $0-80 \mathrm{~cm}$ using a neutron probe. The results highlighted a seasonal pattern ranging from $42 \pm 2 \%$ during the heavy rainy month (August) to $16 \pm 1 \%$ during the dry season (October-November). Significant differences in soil moisture content soil water profile and water stock at depth 0 to $80 \mathrm{~cm}$ were recorded between locations and land use patterns. In general, soil moisture was on average 58\% less in forest island than in croplands across sites. Soil moisture content was lower in topsoil $(0-20 \mathrm{~cm})$ compared to deeper soil $(40-80 \mathrm{~cm})$. The Study demonstrated evident link of soil moisture dynamic with rainfall and the vegetation pattern.
\end{abstract}

(C) 2020 International Formulae Group. All rights reserved.

Keywords: Forest island, soil moisture, savanna, farmland, Burkina Faso.

\section{INTRODUCTION}

Worldwide, there is evidence that land cover change may result in direct or indirect impact on soil properties and processes mainly on hydrological dynamics, which can result to high effect on ecosystem functioning, sustainability and stability (Bond, 2008; Biro et al., 2011; Shabtai et al., 2014).

In this context, important number of studies were carried out in the objective to understand the link between closed vegetation development in savanna and soil hydrology 
(Marston et al., 2018), physical properties and carbon sequestration (Sankaran et al., 2008).

Endeed, Forest islands are dense vegetation with a unique and typical features of tropical rainforest stands of 0.1 to 10 ha in size often found surrounding many village areas in the West African mesic savanna. Unlike to general opinion as relic of former forest, evidence of their anthropogenic origin have been stated (Fairhead and Leach, 2009) and though to be mostly intentionally promoted by the villagers building up suitable conditions for forest development.

Most recent, because of the wider ecological interest of these mosaic environments regarding species richness and biodiversity maintenance (Kokou and Sokpon 2006; Savadogo et al., 2011; Imorou et al., 2017; Marston et al., 2018) and in extent to global carbon stock in soil, their preseravation became a central task. Beside, their establishment in agricultural land have been also recommended (Yin and Liu, 2013) of relevance to sustain (Midgley and Bond, 2015) which may buffer the ongoing pressure on limited, fragile and degraded natural resources (Tappan and McGahuey, 2007). Thus, the success in the background of conservation as well as implementation of these forest island may critically depend on survey mechanisms behind their functionning and the hydrology dynamics.

However, few studies were carried out on the functioning of such "forest islands" (FI), except the descriptive analysis of the vegetation structure and few soil profiles analysis (Sobey, 1978) done for few location. Knowledge about soil processes underlying the formation, maintenance and functionning of these luxuriants forest are still to be clarified in regard of the broad of environmental (savanna) and, socio-cultural features encompassing the forest island formation (Kokou and Sokpon, 2006; Marston et al., 2018).

Soil moisture is the basic component governing ecosystem productivity, fonctionning and suistainability ( $\mathrm{Yu}$ et al., 2015) for both managed and natural ecosystem and was particulary the critical drivers of tropical ecosystem features (Wu et al., 2014). Among others, increased soil moisture have been argued to be an important feature responsible of wood prevalence in savana (Demenois et al., 2017; Gaviria et al., 2017; Marston et al., 2018).

Most studies reported a positive feedback and interactions between soilvegetation and hydrology system (Rietkerk et al., 2000). The mechanism of that feedback inducing forest restoration, improve water availability, increase precipitation (Berg et al., 2014) is an important factor causing the increase of vegetation density in West Africa. Futher, theses feedback may particularly induce changes in soil organic matter, nutrient array (phosphorus and nitrogen) and other key soil processes may promote the establishment of vegetation and subsequently as a consequence, building the patch soil moisture.

Factors that change when a patch of forest is isolated include radiation and consequently, temperature and humidity). As part of the potential range of soil properties and processes that interest environmental, ecological, hydrological and climate system (koster et al., 2004), soil moisture is a dynamic parameter with factors operating at temporal and spatial scales.

There is need to closely investigate the relationship of soil moisture in mediating forest island development. Analysing soil water dynamic in forest island and in its surrounding ecosystems, here farmland and natural savanna, may generate knowledges and evaluate the effect of human disturbance.

\section{MATERIALS AND METHODS}

\section{Descriptions and sampling locations}

The study was carried out from 2016 to 2017 across five sites in Burkina Faso located in two agro ecological zones (AEZ): North Sudanan to South Sudanian for which mean 
annual precipitation ranged from 0.80 to 0.9 $\mathrm{m} \mathrm{a}^{-1}$ (Figure 1). At each site, three land use types were selected and soil sampling as follows:

- The typical hot semiarid forest islands (FI) consisting of patches of forests around villages. They are mosaic landscape of relatively open savanna vegetation and agricultural fields. The trees are 15 to $20 \mathrm{~m}$ tall and of high density ( $>400$ individuals per hectare and diameter $(\mathrm{DBH})>10 \mathrm{~cm})$;

Savanna zones: these entities are more opened than the FIs and are considered as natural vegetation in all the three agro ecological zones (AEZ). The height of the trees was between 5 to $10 \mathrm{~m}$ with lower density of individuals $(<100$ trees/ha and DBH $>10 \mathrm{~cm}$ ) and with a with an abundant ground layer of grasses and herbs;

Cropping areas were selected as closed as possible to the FIs and savanna zones and under cultivation for at least 10 years. In Burkina Faso, the croplands selected were cotton based or cereal based fields.

\section{Biophiysical data collection}

Climatic data (temperature and precipitation) for the sites were obtained from the "'getMet" package of R studio. However, for graphic representation, mean annual precipitation was data collected from rain gauge installed per site during year of study.

Soil type at each site was described following the IUSS-WRB soil classification system after analysis physical and chemical characteristics of samples collected from soil pit. Table1 summarizes the biophysical characteristics $(0-30 \mathrm{~cm}$ depth) of the study sites.

In vegetated soil (forest islands and savanna), four subplots of $20 \times 20 \mathrm{~m}$ were laid out for botanical inventory to species level and trees height and diameter at breast height
(DBH) trees according Torello-Raventos et al. (2013). Additionnaly, for each of the four $20 \mathrm{x}$ 20 subplots, $1.0 \mathrm{~m}^{2}$ quadrat along each gentrytransect was placed on the soil surface at each $5 \mathrm{~m}$, for recording herbaceous ground cover and haversting each species. For detail refer to Veenendaal et al. (2015).

\section{Soil moisture measurement}

The soil moisture content was monitored in Burkina Faso in Forest Island and cropland that are the most contrasted land use situation. The measurement started in February 2016 (dry season) and were made weekly during the rainy season and monthly in the dry season using neutron probe (Campbell Pacific Nuclear Model 503 Hydroprobe). Before monitoring, at each site, three (3) aluminium access tubes per land use were installed to 80 $\mathrm{cm}$ depth. In total, 33 were placed because of included savanna in Dano site. Subsequently, the neutron probe was calibrated to establish linear relationships between neutron probe reading value and the volumetric water content according equation (1). The volumetric soil water content was determined using gravimetric water content and bulk density for each depth increment of $20 \mathrm{~cm}$. The moisture content was expressed as percent water by volume.

$\theta(z)=a X+b \quad$ Equation (1)

With $\theta=$ volumetric water content, $X=$ neutron probe reading, $\mathrm{a}$ and $\mathrm{b}=$ constant

For the calculation of the water stock $\left(\mathrm{S}_{\mathrm{w}}\right)$ in the profile, the following equation (2) was used $\mathrm{S}_{\mathrm{w}}=\sum \theta(z) \quad$ equation (2) where $\theta(\mathrm{z})$ is the water content of the layer.

\section{Statistical analysis}

Statistical analysis of data was performed using Statistix 10 (Ver. 2013) for Analysis of Variance (ANOVA). The separation of means was done using Tukey's test at the probability of 5.\%. 


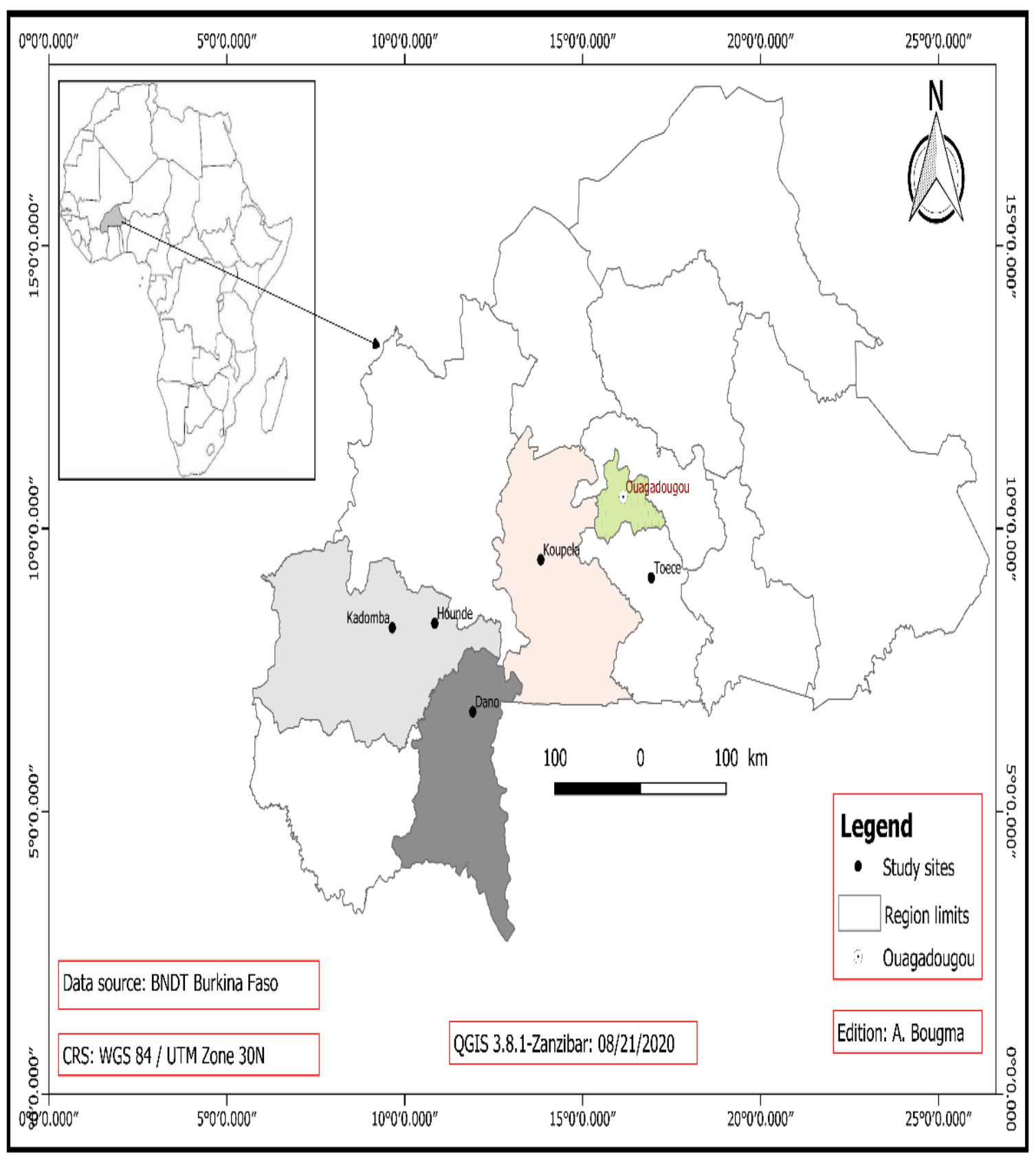

Figure 1: Location of study sites. 
Table 1: Biophysical properties $(0-30 \mathrm{~cm})$ of the sites.

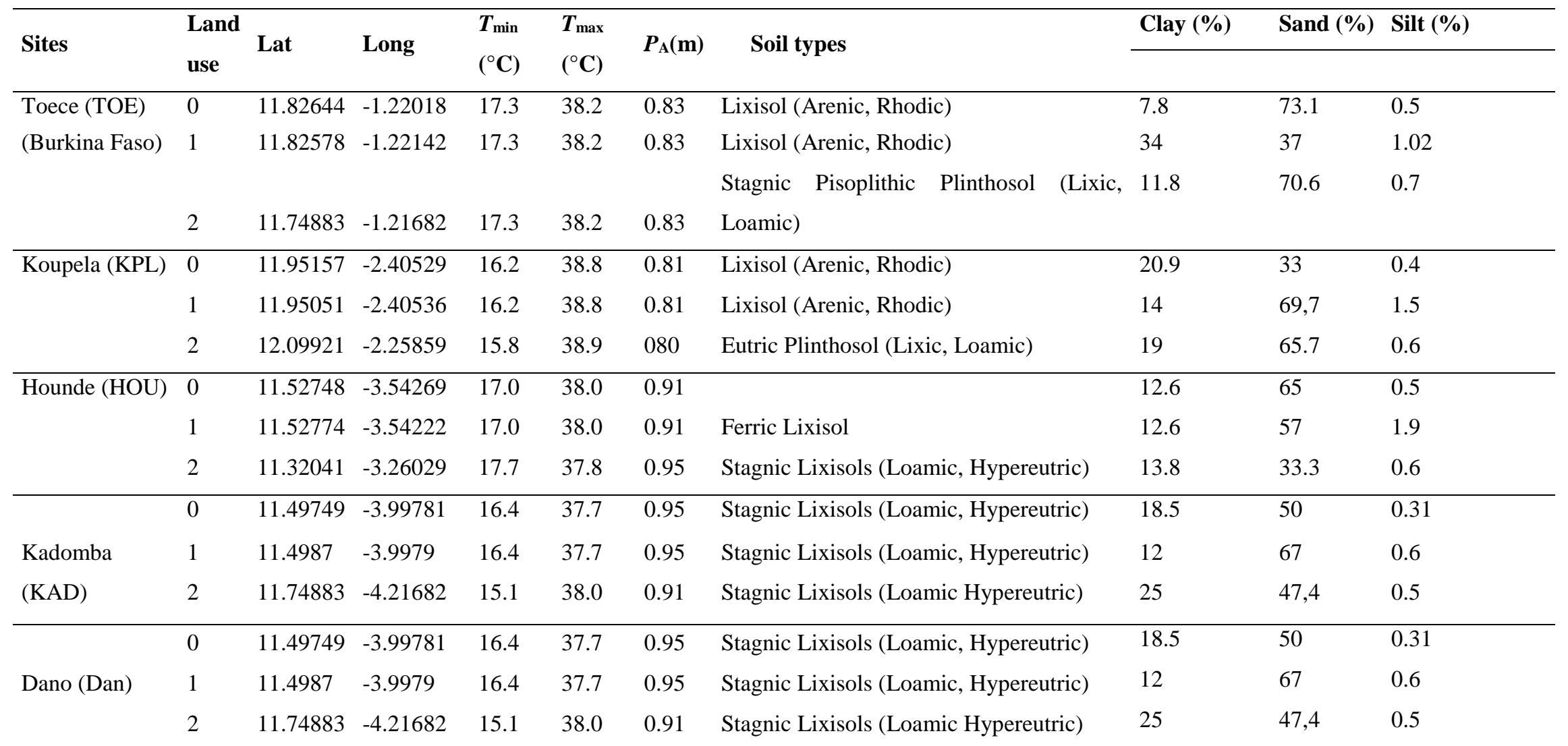

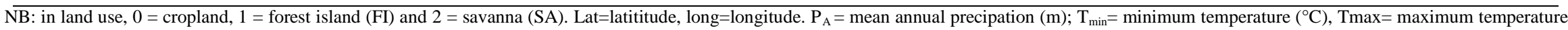
$\left({ }^{\circ} \mathrm{C}\right)$. 


\section{RESULTS}

The data showed significant differences in soil moisture $(P<0.001)$ between sites, land use type, date and soil depth with interactions between factors (Table 2).

\section{Variation of moisture $(0-30 \mathrm{~cm})$ according to land use across site in 2016.}

In all the sites, there was a seasonal pattern $(\mathrm{P}<0,001)$ of soil moisture characterized by a progressive increase at the beginning of the rainy season followed by a peak during the wet season (August) and a decrease in soil moiture at the start of the dry season (October-November) (Figures 2; 3: 4; 5). Thus, soil moisture content changed considerably between measurement dates $(\mathrm{P}<$ 0:001), and ranged from $42 \pm 2 \%$ during the full rainy season to the low value of $16 \pm 1 \%$ in the dry season.

The highest differences in soil water contents between land use types were recorded at Toece and Houndé (Figures 2 and 3) whereas Kadomba and Koupela showed small differences between land uses (Figures 4 and 5), althought the forest island was different from the savanna and the farmland at Dano (Figure 6).

The soil moisture was higher on the farmland than in the forest island at Toécé, Houndé and Koupela (Figures 2; 3; 5). It was on average $58 \%$ less than in croplands (Figures 2 and 3 ).

At Kadomba the reverse situation was found comparing the two land use types (Figure 5), with significant differences in soil moisture recorded during the study period.

However, at Dano, the dynamic of soil moisture observed between land uses had very different patterns of variation (Figure 6). From June to mid-september, soil moisture was higher in farmland and savana compared to Forest Island. But at the end of the rainy season, mid-september to November, the soil water content was the highest in the forest island.

\section{Soil water content profiles distribution over seasons}

There were changes in soil water content profiles across the dry and the rainy season in the farmland as well as in the forest islands and savanna vegetation cover. The soil water profiles show the same pattern as soil water content over time on 0-30 cm soil layer. Soil moisture content varied significantly $(P<$ $0.001)$ througout the soil profile and over time, but with the influence of location (Figures 7; 8 and 9). Significant differences were found in soil moisture profiles between land use and between different periods of the season. At all sites, there was a significant difference between top soil $(0-20 \mathrm{~cm})$ water content and the sub-layer $(60-80 \mathrm{~cm})$ which had the highest moisture (Figures 7, 8 and 9).

The pattern of soil water profiles was the same over time and land use effect for the sites of Toéce (presented here in figure 7), Koupéla and Houndé. In these sites, the soil water content was signicantly higher in the farmland than in the forest island throughout the season and soil depth, except the beginning of the rainy season in soil top layer, $0-20 \mathrm{~cm}$ where the farmland was the driest (Figure 7a).

At the site of Kadomba, there was not significant diference in soil water content in the top layer $0-20 \mathrm{~cm}$ during the three selected periods of the season. In the deeper layers, soil water profiles indicated a higher soil moisture in the forest island s compared to the farmland (Figure 8). It was the opposite in the sites of Toécé, Koupéla and Houndé where the forest island showed higher soil water content in the soil profile than in the farmland.

At Dano, in May at the beginning of the rainy season, soil water contents were low in the soil upper layer without significant differences between the forest island, the savanna as well as the farmland (Figure 9a). In the deepper layer $(40-80 \mathrm{~cm})$ the soil moisture was higher in the forest island following by the farmland than for the savanna vegetation cover (Figure 9). The same pattern was recorde at the end of the rainy season in November except that the farmland was drier in the soil surface than the forest island and the savanna (Figure 
9c). At the mid-rainy season (August), the soil profiles were almost saturated in all land use types. In the soil upper layer $(0-20 \mathrm{~cm})$ the water content was the highest in the farmland compared to the forest island and the savanna (Figure 9b).

\section{Variation of stock of water $(0-80 \mathrm{~cm})$ according to soil occupation}

Similar to the moisture contents at soil layer $0-30 \mathrm{~cm}$ and the soil water content profiles; the stock of water at $0-80 \mathrm{~cm}$ depth showed the same trend; differences between sites and land uses, and over the years. The stock of water values was significantly higher during the rainy than during the dry season $(\mathrm{P}$ $<0.001$ ) (Figures 10; 11; 12; 13; 14). The stock of water, in 0-80 $\mathrm{cm}$ soil depth, was higher in the cropland ( 156 to $298 \mathrm{~mm}$ ) than in the forest island ( 83 to $219 \mathrm{~mm}$ ) at Toécé, Koupela and Houndé sites. At the same soil depth, the water stock was significally higher in the forest island than in the farmland at Kadomba, while at Dano the farmland was in between the Forest Island and the savanna at the beginning of the rainy season. From July to mid-september, the farmland and the savanna had similar water stock varing between $350 \mathrm{~mm}$ and $400 \mathrm{~mm}$ and higher than the stock in the forest island (Figure 14). At the end of the rainy season, during the drying process, the soil water stock dropped sharply to reach $205 \mathrm{~mm}$ in the savanna and the farmland and $263 \mathrm{~mm}$ in the forest island (Figure 14).

Table 2: Analysis of Variance (ANOVA) table for soil moisture content, Burikina 2016.

\begin{tabular}{llllll}
\hline Source & DF & SS & MS & F & Pr \\
\hline Site & 3 & 15300,4 & 5100,1 & 225,83 & $<0,001$ \\
Land use & 1 & 14231,5 & 14231,5 & 630,16 & $<0,001$ \\
Date & 9 & 17763,8 & 1973,8 & 87,4 & $<0,001$ \\
Depth & 3 & 20580,5 & 6860,2 & 303,77 & $<0,001$ \\
Site * Land use & 3 & 23988,1 & 7996 & 354,06 & $<0,001$ \\
Site *Date & 27 & 4847,89 & 179,6 & 7,95 & $<0,001$ \\
Site * Depth & 9 & 2249,67 & 250 & 11,07 & $<0,001$ \\
Land use*Date & 9 & 1092,02 & 121,3 & 5,37 & $<0,001$ \\
Land use* Depth & 3 & 608,259 & 202,8 & 8,98 & $<0,001$ \\
Site * Land use*Date & 27 & 1143,43 & 42,3 & 1,88 & 0,005 \\
Site * Land use* Depth & 9 & 2125,43 & 236,2 & 10,46 & $<0,001$ \\
Site* Land use*Date* Depth & 216 & 7696,22 & 35,6 & 1,58 & $<0,001$ \\
Error & 622 & 14047,1 & 22,6 & & \\
Total & 941 & & & & \\
\hline & & & & & \\
\hline
\end{tabular}

DF: Degree of Freedom, SS: Square Sums, Ms: Means of Square, Pr: Probability. Significant differences: * P=0.05; ** P=0.01; $* * * \mathrm{P}=<0.001$ 


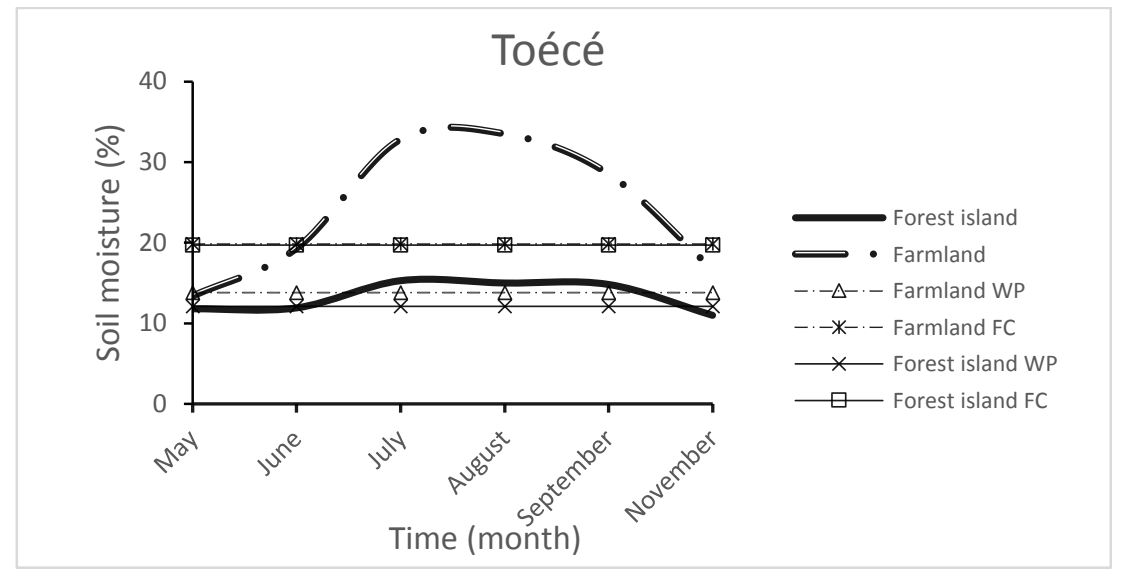

Figure 2: soil moisture over season according to land use at Toécé. $\mathrm{WP}=$ welting point; $\mathrm{FC}=$ Field capacity.

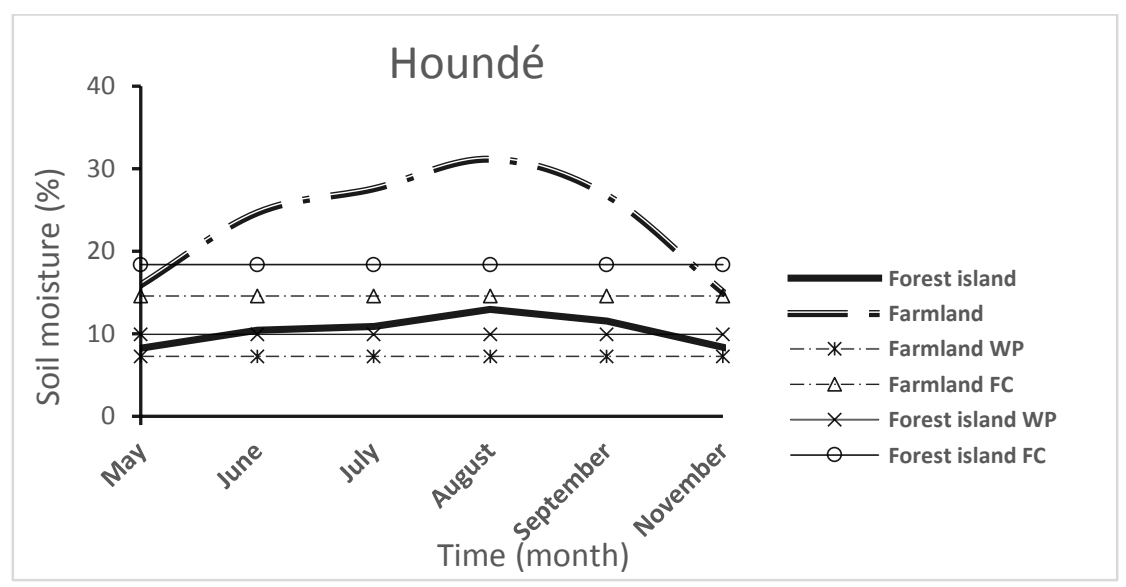

Figure 3: soil moisture over season accordind to land use at Hounde, $(0-30 \mathrm{~cm})$ layer. $\mathrm{WP}=$ welting point; $\mathrm{FC}=$ Field capacity.

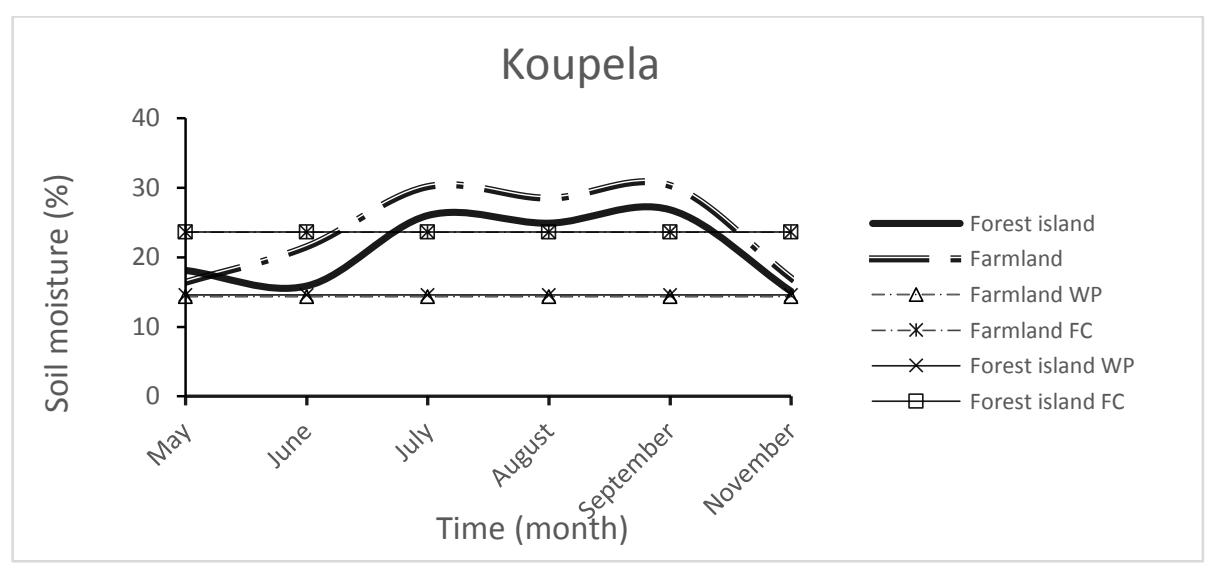

Figure 4: soil moisture over season accordind to land use at Koupela, $(0-30 \mathrm{~cm})$ layer. $\mathrm{WP}=$ welting point; $\mathrm{FC}=$ Field capacity. 


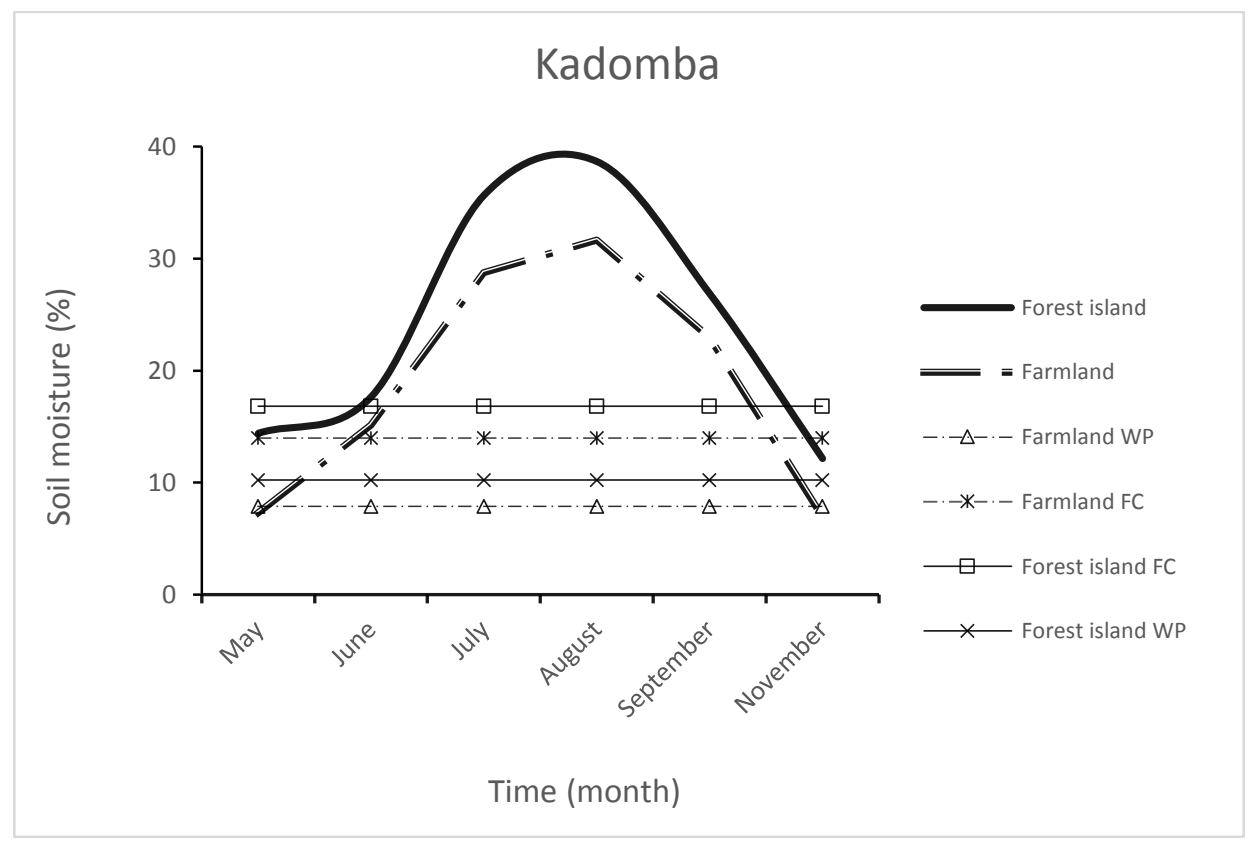

Figure 5: soil moisture over season accordind to land use at Kadomba, $(0-30 \mathrm{~cm})$ layer. $\mathrm{WP}=$ welting point; $\mathrm{FC}=$ Field capacity.

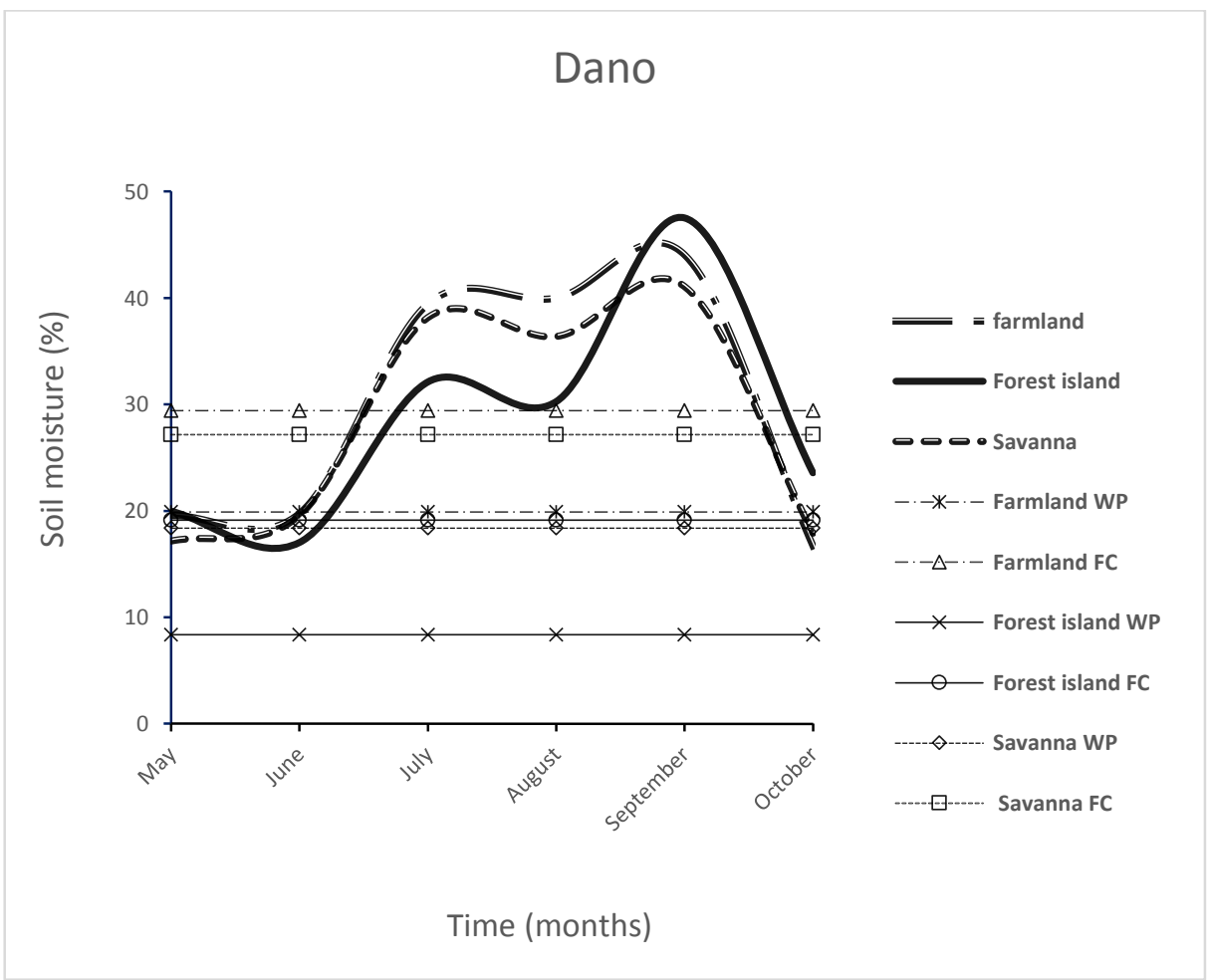

Figure 6: soil moisture over season accordind to land use at Dano, $(0-30 \mathrm{~cm})$ layer. $\mathrm{WP}=$ welting point $\mathrm{FC}=$ Field capacity. 
(a)

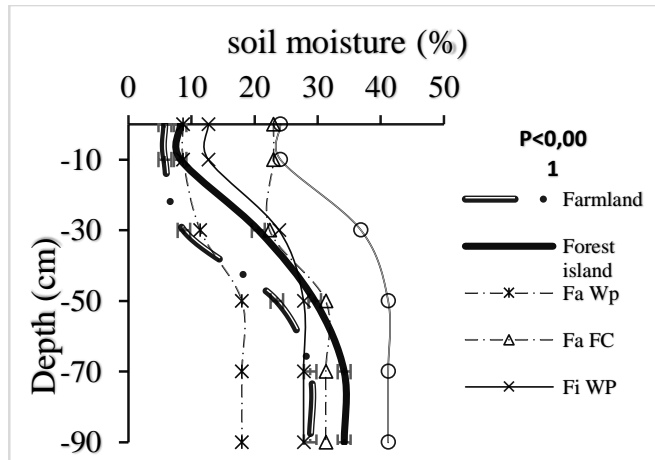

Early season (May, 2016) (b)

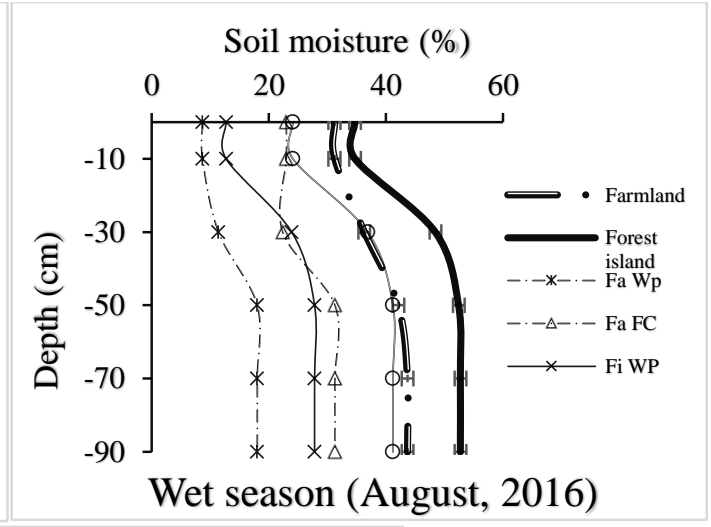

Soil moisture $(\%)$

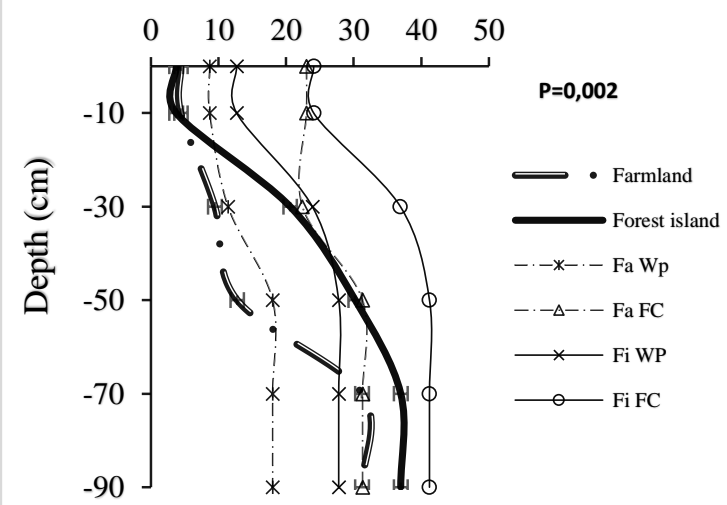

Dry season (November, 2016)

Figure 7: soil water content profiles over the dry and wet season 2016 at Toece: (a) in may; (b) in august; (c) in November.

$\mathrm{Fa} \mathrm{WP}$ =farmland welting point; $\mathrm{Fa} \mathrm{FC}=$ farmland field capacity, $\mathrm{Fi} \mathrm{WP}=$ forest island welting point; $\mathrm{Fi} \mathrm{FC}=$ forest island field capacity.

(a)

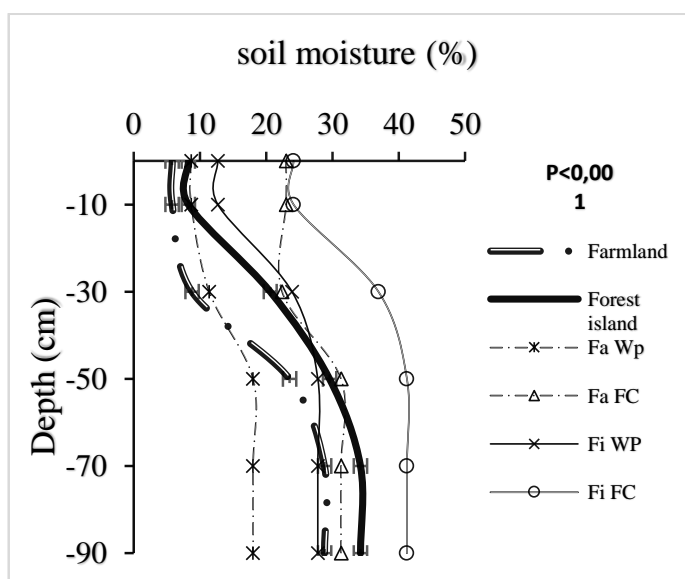

Early season (May, 2016) (b)

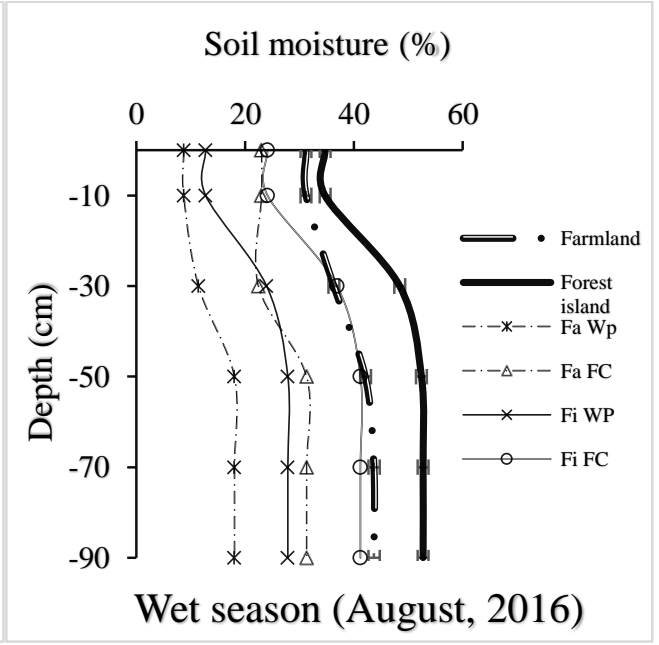




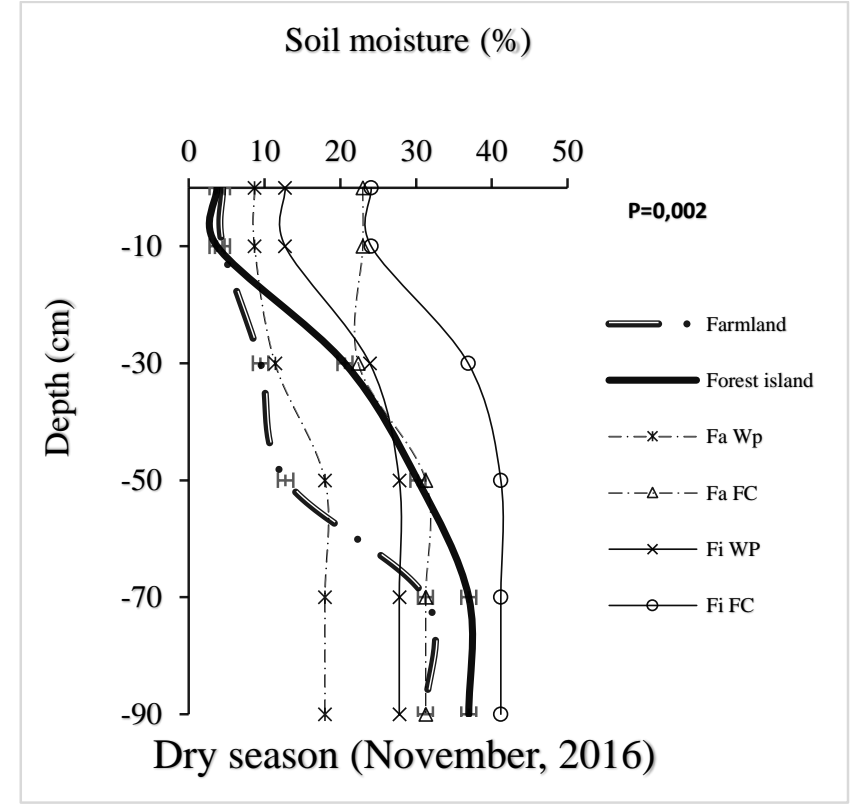

(a)

(b)

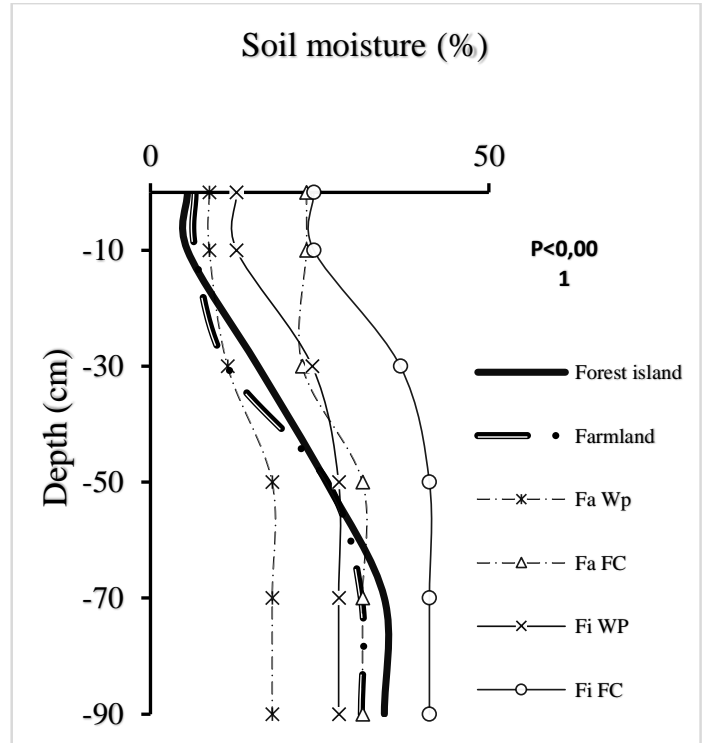

Early season (May, 2017)
Soil moisture (\%)

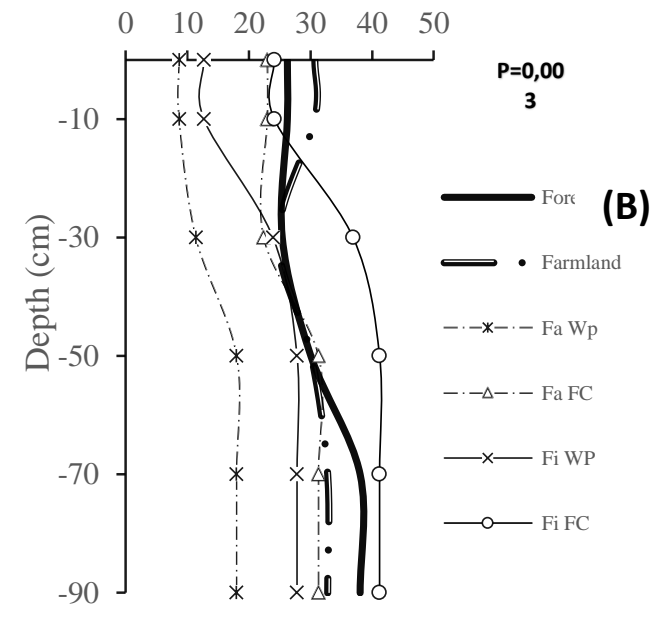

Wet season (August, 2017)

Figure 8: soil water content profiles over the dry and wet season 2016 and 2017 at Kadomba: (a) in may; (b) in august; (c) in november.

$\mathrm{Fa} \mathrm{WP}$ =farmland welting point; $\mathrm{Fa} \mathrm{FC}=$ farmland field capacity, $\mathrm{Fi} \mathrm{WP}=$ forest island welting point; $\mathrm{Fi} \mathrm{FC}=$ forest island field capacity. 
(a)

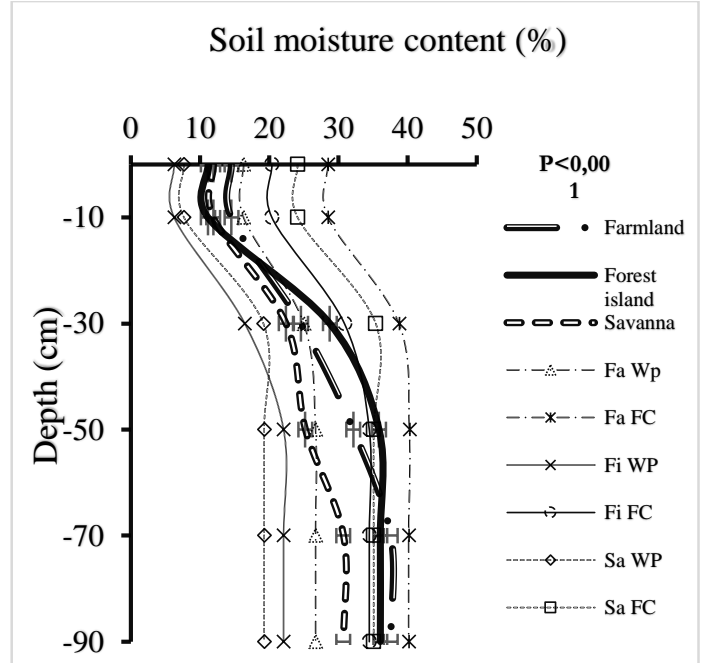

Early season (May, 2016) (b)
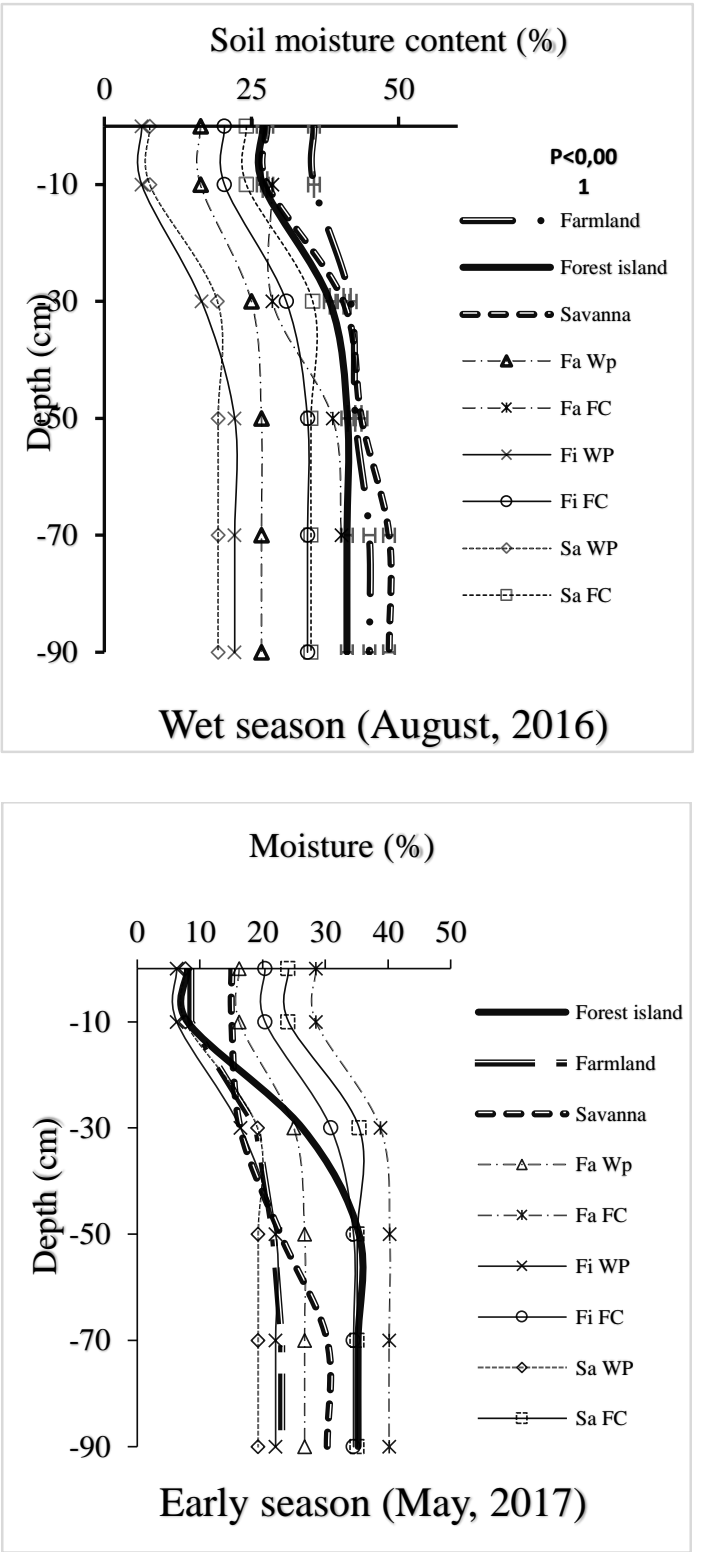

Figure 9: soil water content profiles over the dry and wet season 2016 and 2017 at Dano: (a) in may; (b) in august; (c) in November.

$\mathrm{Fa} \mathrm{WP}$ =farmland welting point; $\mathrm{Fa} \mathrm{FC}=$ farmland field capacity, $\mathrm{Fi} \mathrm{WP}=$ forest island welting point; $\mathrm{Fi} \mathrm{FC}=$ forest island field capacity, $\mathrm{Sa} \mathrm{WP}=$ savana welting point; $\mathrm{SaFC}=$ savana field capacity. 


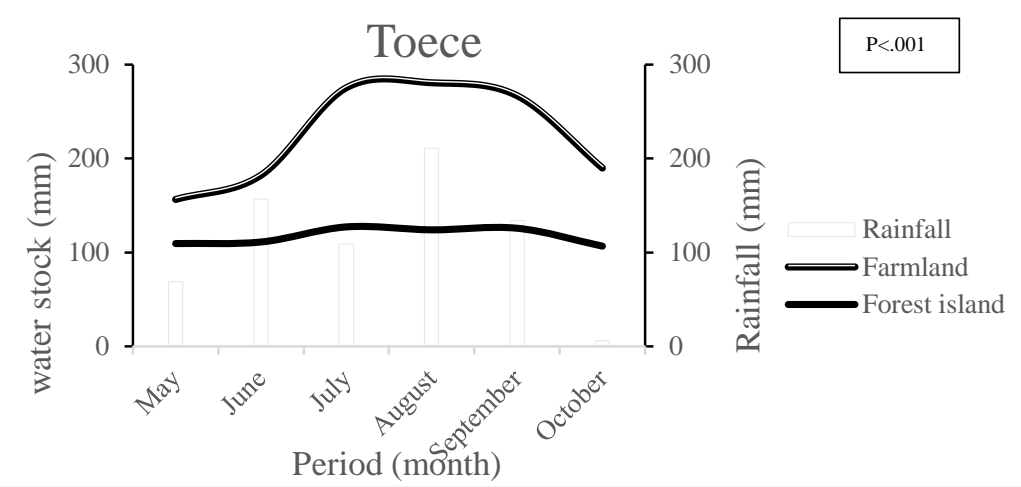

Figure 10: Stock of water on soil layer 0-80 cm over season according to land use at Toéce (2016).

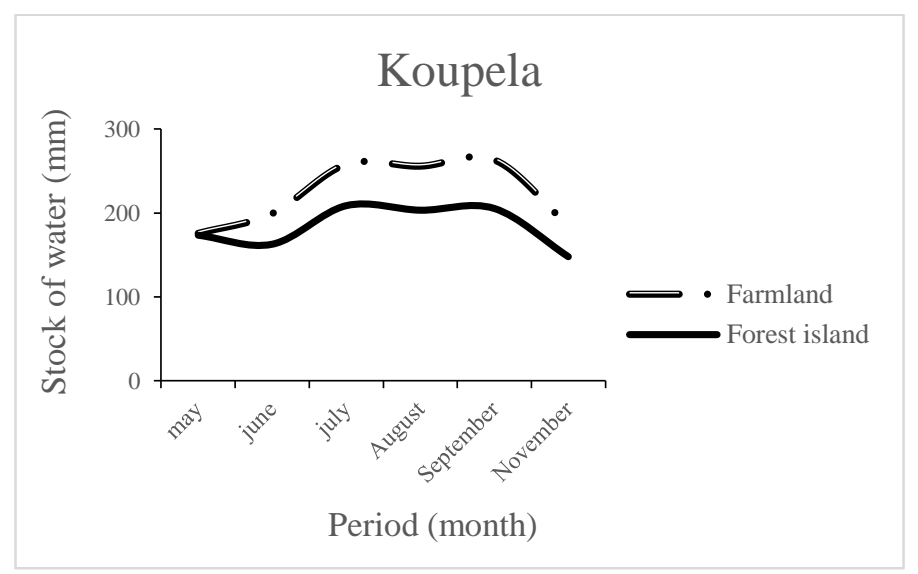

Figure 11: Stock of water on soil layer 0-80cm over season according to land use at Koupela (2016).

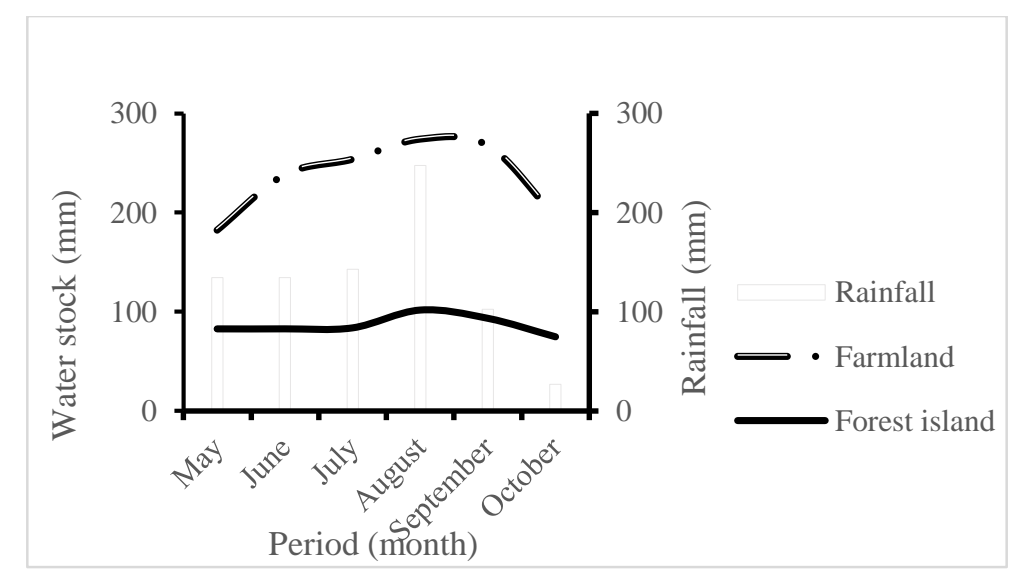

Figure 12: Stock of water on soil layer $0-80 \mathrm{~cm}$ over season according to land use at Houndé (2016). 


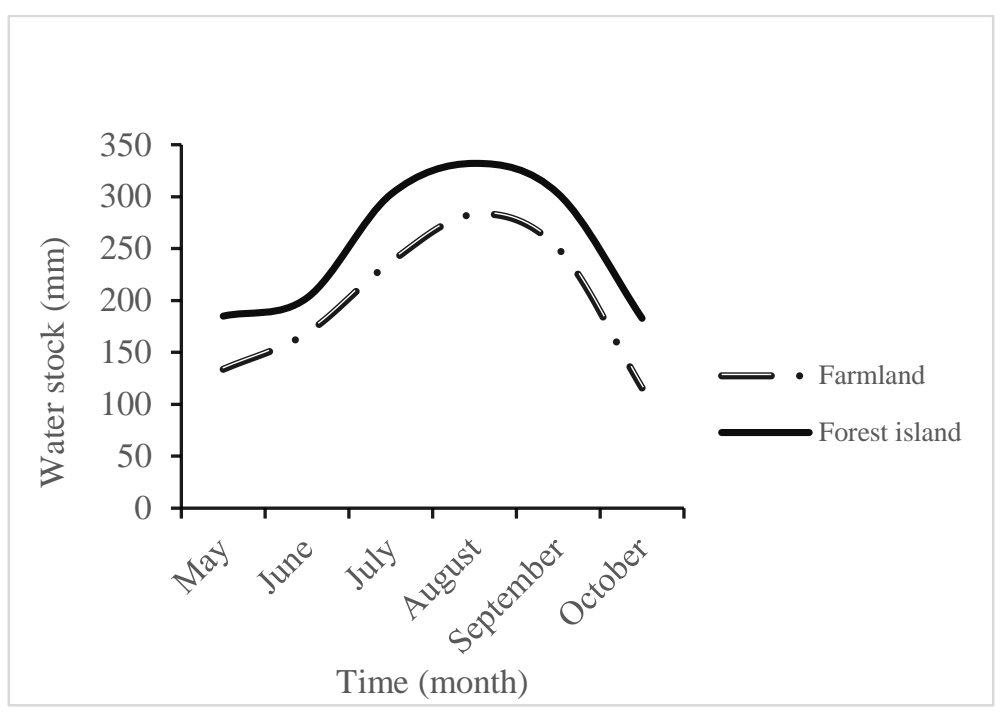

Figure 13: Stock of water on soil layer 0-80cm over season according to land use at Kadomba (2016).

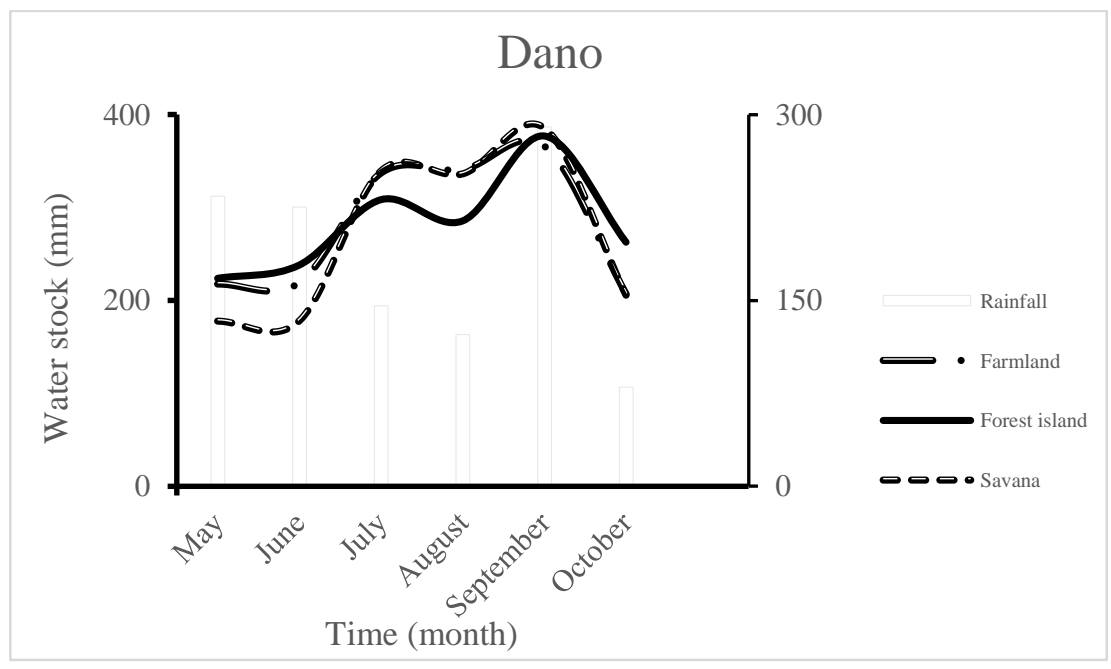

Figure 14: Stock of water on soil layer 0-80cm over season according to land use at Dano (2016).

\section{DISCUSSION}

The monitoring of soil moisture dynamics in forest island, farmland and savanna ecosystems indicated a seasonality in the pattern of soil water contents. Before the onset of the rainy season the soil is dry and the soil water content is below the wilting point in all land use types. At the start of the rainy season, in May, the soil moisture increases to reach a peak occurring mainly in mid rainy season (August). As the rainfall decreases toward, the end of the raining season the soil water content decreases to the low value in the dry season. This general trend of soil water content dynamic is governed by the rainfall pattern and this was also reported by many authors (Macfarlane et al., 2007; Lal, 2015; Rowland et al., 2017; Bach and Hofmockel, 2017; Yang et al., 2019). Bonan et al. (2016) and Scott et al. (2019) found also that precipitation is the major source of soil moisture in drylands as it is the case in sub Saharan Africa. Gao et al. (2014) found also positive correlation between soils surface water 
content and precipitation events. The soil moisture increases after rainfall and decreases during dry periods. Indeed, the soil water content was higher in the southern region with higher annual rainfall than the northern region regardless of the land use. Hence, Toece, Koupela and Hounde, located in the northern part of the country, had lower soil water content than the two sites, Kadomba and Dano.

The same trends were found with soil water profiles dynamic and soil water stock in 0-80 $\mathrm{cm}$ soil depth. The differences observed between the sites for soil water content, soil water profiles during different periods of the season and. can be explained by the soil heterogeneity (bulk density, texture) (Bronick and Lal, 2005), differences in amount and distribution of annual rainfall and the density of the vegetation as indicated by Bronick and Lal (2005). The forest island soil water content is lower than that of the farmland in Toece, Koupela and Houndé. In the sites of Kadomba and Dano, the lower soil moisture content was recorded in the farmland can be explained by the soil water content between land uses attributed to the lower soil bulk density recorded in the farmland. Those results are similar to those reported by- Wang et al., (2012; 2016) who indicated higher soil water content of cropland than in caragana forest soil profile of China.

A negative Pearson correlation was found between soil moisture and soil bulk density $(r=-0.635, P=0.035)$. The farmland had lower bulk density on $0-30 \mathrm{~cm}$ soil layer than the forest island, due to soil tillage for seedbed preparation. This disturbance in soil top layer increases soil porosity and consequently more water infiltration leading to soil moisture improvement (Ouattara et al., 2011; Serme et al., 2015; Yu et al. 2015; Ouattara et al., 2018). In contrary, Maqboul et al. (2017) found in India, that soil bulk density and moisture were lower in forest than agriculture land.

Forest islands are often open to domestic animals grazing, then animal trampling can compact soil surface layer reducing rain water infiltration into the soil. In addition, at the onset of the rainy season the forest vegetation become physiologically very active as response to the precipitation input, as soil moisture increase (Brown-Mitica et al., 2007). The trees evapotranspiration increases at the dependency of soil water content. The differenre in crop and trees rooting system may also account for the difference in soil water content between farmland and forest island. Tree roots transfer quantities of water downward to dry soil layers when surface soil layers become wet after rain events (Stephen et al., 2001; Miriti et al., 2013). The benefit of this mechanism is the increase in soil moisture in dry subsoils.

The size of the sites of Toece, Koupela and Houndé were less than 3 ha, while Kadomba and Dano had more than 10 ha. In addition, trees densities were 694, 656 and 444 plants ha $^{-1}$ at Toece, Koupela and Houndé respectively, while the trees density was more than 1100 stands ha ${ }^{-1}$ at Kadomba and Dano. Ranney et al. (1981), Kapos (1989) reported that when a patch of forest is isolated, strong wind and radiation would increase evapotranspiration and decrease soil moisture unless the trees react by restricting their water loss. Then small forest island may have lower soil moisture content than large forest island in similar biophysical conditions.

\section{Conclusion}

The study showed that soil moisture dynamics in forest island and adjacent ecosystem is basically governed by the pattern of the rainfall events over the year seasons. Change in the top soil physical properties with human disturbance, especially tillage, overgrazing and animal trampling has strong impact on soil moisture in the Forest Island and adjacent ecosystem. In addition, the size of the forest island and its trees density affects soil moisture over time throughout the soil profile. Small size Forest Island has lower soil water content than farmland. The reverse situation is observed with large size Forest Island especially at the end of the rainy season.

\section{ACKNOWLEDGMENTS}

The authors are grateful to local village occupants for their collaboration and field assistance. We also thank the Laboratory of physics INERA- Saria local village occupants for their collaboration and field technical assistance in water potential characterization. 


\section{COMPETING INTERESTS}

The authors declare that they have no competing interests.

\section{AUTHORS' CONTRIBUTIONS}

ABB conducted fieldwork, analyzed data, and wrote the manuscript; $\mathrm{KO}$ oriented the study and corrected the manuscript. All authors contributed in writting and reviewing the manuscript.

\section{REFERENCES}

Bach EM, Hofmockel KS. 2015: A time for every season: soil aggregate turnover timulates decomposition and reduces carbon loss in grasslands managed for bioenergy, GCB Bioenergy, 8(3): 588599. DOI: $10.1111 / \mathrm{gcbb} .12267$.

Berg A, Lintner BR, Findell KL, Malyshev S, Loikith PC, Gentine P. 2014. Impact of Soil Moisture - Atmosphere Interactions on Surface Temperature Distribution. Journal of Climate, 27. DOI: https://doi.org/10.1175/JCLI-D-1300591.1.

Biro K, Pradhan B, Buchroithner M, Makeschin F. 2011. Land Use / Land Cover Change analysis and its impact on soil properties in the Northern part of Gadarif region, Sudan. Land Degrad. Develop. DOI: 10.1002/ldr.1116.

Bonan L, Wang L, Kaseke KF, Li L, Seely MK. 2016. The impact of rainfall on soil moisture dynamics in a Foggy desert. PloS One, 11(10): 1-17. DOI: 10.1371/journal.pone.0164982.

Bond WJ. 2008. What Limits Trees in C4 Grasslands and Savannas? Annual Review of Ecology, Evolution, and Systematics, 39(1): 641-59. DOI: https://doi.org/10.1146/annurev.ecolsys. 39.110707.173411.

Bronick CJ, Lal R. 2005. Soil Structure and Management: A Review. J. Geoderma, 124: 3-22. DOI: https://doi.org/10.1016/j.geoderma.2004. 03.005 .

Brown-Mitica C, Shuttleworthb WJ, Harlowc RC, Pettib J, Burkec E, Bales R. 2007. Seasonal water dynamics of a sky island subalpine forest in semi-arid southwestern United States. Journal of Arid Environments, 69(2007): 237-258.

Demenois J, Carriconde F, Rey F, Stokes A. 2017. Tropical plant communities modify soil aggregate stability along a successional vegetation gradient on aferralsol. Ecological Engineering, 1: 111.

DOI: https://doi.org/10.1016/j.ecoleng.2017.07 .027 .

Fairhead J, Leach M. 2009. Amazonian Dark Earths in Africa? Amazonian Dark Earths: Wim Sombroek's Vision, WI Woods, WG Teixeira, Lehmann J, Steiner C, WinklerPrins AMGA, Rebellato L (eds). Springer: Berlin-Allemagne; 265-278.

Gao X, Wu P, Zhao X, Wang J, Shi Y. 2014. Effects of landuse on soil moisture variation in a semi arid catchment: implications for land and agricultural water. Journal of Land Degrad. Develop., 25: 163-172.

Gaviria J, Turner BL, Engelbrecht BMJ. 2017. Drivers of tree species distribution across a tropical rainfall gradient. Ecosphere, 8(2): $\quad$ e01712. https://doi.org/10.1002/ecs2.1712

Imorou1 IT, Arouna1 O, Houessou LG, Sinsin B. 2017. Contribution of sacred forests to biodiversity conservation: case of Adjahouto and Lokozoun sacred forests in southern Benin, West Africa. Int. J. Biol. Chem. Sci., 11(6): 2936-2951. DOI: 10.4314/ijbcs.v11i6.30

Kokou K, Sokpon N. 2006. Les Forêts sacrées du couloir du Dahomey." Bois et Forêts des Tropiques, 288: $2 . \quad$ DOI: https://doi.org/10.19182/bft2006.288.a20 312

Koster RD, Dirmeyer PA, Guo Z, Bonan G, Chan E, Cox P, Gordon CT, Kanae S, Kowalczyk E, Lawrence D, Liu P, Lu Cheng-Hsuan, Malyshev S, McAvaney B, Mitchell K, Mocko D, Oki T, Oleson K, Pitman A, Sud YC, Taylor CM, Verseghy D, Vasic R, Xue Y, Yamada T. 2004. Regions of Strong Coupling Between Soil Moisture and Precipitation. Science, 305: $1138 . \quad$ DOI: 10.1126/science. 1100217 
Lal R. 2015. Restoring Soil Quality to Mitigate Soil Degradation. Sustainability, 7: 58755895.

DOI: https://doi.org/10.3390/su7055875.

Liu HY, Yin Y. 2013. Response of forest distribution to past climate change: An insight into future predictions. Chin. Sci. Bull., 58: 4426-4436. DOI: 10.1007/s11434-013-6032-7

Macfarlane C, Hoffman M, Eamus D, Kerp N, Higginson S, Mcmurtrie R, Mark A. 2007. Estimation of Leaf Area Index in Eucalypt Forest Using Digital Photography. J. Agrformet., 143: 176-88. https://doi.org/10.1016/j.agrformet.2006. 10.013 .

Maqbool M, Shafi S, Rehman NZ. 2017. Comparison between Forest and Agriculture Land uses in Relation to Physico-chemical Properties and Nutrient Status of Soil in district Ganderbal J \& K. Research Journal of Agricultural Sciences, 8(3): 559-566.

Marston CG, Wilkinson DM, Reynolds SC, Louys J, O'Regan HJ. 2018. Water Availability is a Principal Driver of Large-Scale Land Cover Spatial Heterogeneity in Sub-Saharan Savannahs. Landscape Ecology, 9. DOI: https://doi.org/10.1007/s10980-0180750-9.

Midgley GF, Bond WJ.2015. Future of African Terrestrial Biodiversity and Ecosystems under Anthropogenic. Climate Change/ Nature Climate, 5(9): 823-29. DOI: https://DOI.org/10.1038/nclimate2753.

Miriti JM, Kironchi G, Esilaba AO, Gachene CKK, Heng LK, Mwangi DM. 2013. The Effects of Tillage Systems on Soil Physical Properties and Water Conservation in a Sandy Loam Soil in Eastern Kenya. Journal of Soil Science and Environmental Management, 4(7): 146-54.

DOI: https://doi.org/10.5897/JSSEM2013.039 5.

Ouattara B, Coulibaly K, Kohio E, Doumbia S, Ouédraogo S, Nacro HB. 2018. Effets du Système de Culture sous couverture Végétale (SCV) sur les flux hydriques d'un sol ferrugineux à l'Ouest du Burkina Faso. Int. J. Biol. Chem. Sci., 12(4): 1770-
1783.

DOI: https://dx.doi.org/10.4314/ijbcs.v12i4.20 Ouattara K, Nyberg G, Ouattara B, Sedogo PM, Malmer A. 2011. Performances of cotton-maize rotation system as affected by ploughing frequency and soil fertility management in Burkina Faso. In Innovations as Key to the Green Revolution in Africa: Exploring the Scientific Facts, Bationo A, Waswa B, Okeyo J, Maina F, Kihara J (eds). Springer Science+Business Media: Germany; 563-570. DOI: https://doi.org/10.1007/978-90-4812543-2_82.

Rietkerk M, Ketner P, Burger J, Hoorens B, Olff H. 2000. Multiscale soil and vegetation patchiness along a gradient of herbivore impact in a semi-arid grazing system in West Africa. Plant Ecol., 148(2): 207-224.

Rowland L, Zaragoza-castells J, Bloomfield KJ, Turnbull MH, Bonal D, Burban B, Norma S, Cosio E, Metcalfe DJ, Ford A, Phillips OL, Atkin OK, Mei P. 2017. Scaling Leaf Respiration with Nitrogen and Phosphorus in Tropical Forests across Two Continents. New Phytologist, 214:13992.

DOI: https://doi.org/10.1111/nph.13992.

Sankaran, M, Ratnam J, Hanan N. 2008. Woody Cover in African Savannas: The Role of Resources, Fire and Herbivory. Global Ecology and Biogeography, 17(2): 236-45. DOI: https://doi.org/10.1111/j.14668238.2007.00360.x.

Savadogo S, Kabore A, Thiombiano A. 2017. Caractéristiques végétales, typologie et fonctions des bois sacrés au Burkina Faso. Int. J. Biol. Chem. Sci., 11(4): 14971511. DOI: $10.4314 /$ ijbcs.v11i4.8

Scott TA, Kirchner JW, Braun S, Siegwolf RTW, Goldsmith GR. 2019. Seasonal origins of soil water used by trees. Hydrol. Earth Syst. Sci., 23: 1199-1210. DOI: https://doi.org/10.5194/hess-231199-2019.

Serme I, Ouattara K, Logah V, Taonda JB, Pale S, Quansah C, Abaidoo CR. 2015. Impact of tillage and fertility management options on selected soil physical 
properties and sorghum yield. Int. J. Biol. Chem. Sci., 9(3): 1154-1170. DOI: 10.4314/ijbcs.v9i3.2

Shabtai, I A, Shenker M, Edeto W L, Warburg A, Ben-hur M. 2014. Effects of Land Use on Structure and Hydraulic Properties of Vertisols Containing a Sodic Horizon in Northern Ethiopia Soil \& Tillage Research Effects of Land Use on Structure and Hydraulic Properties of Vertisols Containing a Sodic Horizon in Northern Ethiopia. Soil \& Tillage Research, 136: 19-27. DOI: https://doi.org/10.1016/j.still.2013.09.007.

Stephen SO, Burgess MA, Adams NC, TDA White, CK Ong. 2001. Tree roots: conduits for deep recharge of soil water. Oecologia, 126: 158-165 DOI: 10.1007/s004420000501

Sobey. DG. 1978. Anogeissus groves on abandonned village sites in the Mole National Park, Ghana. Biotropica, 10(2): 87-99.

Tappan Gray, and Michael McGahuey. 2007. Tracking Environmental Dynamics and Agricultural Intensification in Southern Mali. Agricultural Systems, 94(1): 38-51. DOI:

https://doi.org/10.1016/j.agsy.2005.07.01 1.

Torello-Raventos M, Feldpauschb TR, Veenendaal E, Schrodt F, Saiz G, Domingues TF, Djagbletey G, Ford A, Kemp J, Marimon BS, Junior BHM, Lenza E, Ratter JA, Maracahipes L, Sasaki D, Sonké B, Zapfack L, Taedoumg H, Villarroel D, Schwarz M, Quesada CA, Ishida FY, Nardoto GB, AffumBaffoe K, Arroyo L, Bowman DMJS, Compaore H, Davies K, Diallo A, Fyllas NM, Gilpin M, Hien F, Johnson M, Killeen TJ, Metcalfe D, Miranda HS, Steininger M, Thomson J, Sykora K, Mougin Eric, Hiernaux P, Bird MI, Grace J, Lewis SL, Phillips OL, Lloyd J. 2013. On the delineation of tropical vegetation types with an emphasis on forest/savanna transitions. Plant Ecology and Diversity, 6(1): 101-137. DOI: http://dx.doi.org/10.1080/17550874.2012 .762812 .

Veenendaal EM, Torello-Raventos M, Feldpausch TR, Domingues TF, Gerard F, Schrodt F, Saiz G, Quesada CA, Djagbletey G, Ford A, Kemp J, Marimon BS, Marimon-Junior BH, Lenza E, Ratter JA, Maracahipes L., Sasaki D, Sonké B, Zapfack L, Villarroel D, Schwarz M, Yoko Ishida, Gilpin M, Nardoto GB, Affum-Baffoe K, Arroyo L, Bloomfield K, Ceca G, Compaore H, Davies K, Diallo A, Fyllas NM, Gignoux J, Hien F, Johnson M, Mougin E, Hiernaux P, Killeen T, Metcalfe D, Miranda HS, Steininger M, Sykora K, Bird MI, Grace J, Lewis S, Phillips OL, Lloyd J. 2015. Structural, physiognomic and aboveground biomass variation in savanna-forest transition zones on three continents. How different are cooccurring savanna and forest formations? Biogeosciences, 12: 2927-2951. DOI:10.5194/bg-12-2927-2015

Wang S, Fu BJ, Gao GY, Yao XL, Zhou J. 2012. Soil moisture and evapotranspiration of different land cover types in the Loess Plateau, China. Hydrol. Earth Syst. Sci., 16, 2883-2892. DOI:10.5194/hess-16-2883-2012.

Wang A, Liu B, Wang Z, Liu G. 2016. Monitoring and predicting the soil water content in the deeper soil profile of Loess Plateau, China. International Soil and Water Conservation Research, 4: 6-11. DOI:

https://doi.org/10.1016/j.iswcr.2016.02.001

Yang B, Lee DK, Heo HK, Biging G. 2019. The efects of tree characteristics on rainfall interception in urban areas. Landscape and Ecological Engineering, 15: 289-296. DOI: https://doi.org/10.1007/s11355-01900383-w.

Yu Y, Wei W, Chen LD, Jia FY, Yang L, Zhang HD, Feng TJ. 2015. Responses of Vertical Soil Moisture to Rainfall Pulses and Land Uses in a Typical Loess Hilly Area, China. Solid Earth, 6: 595-608. DOI: $10.5194 / \mathrm{se}-6-595-2015$. 